\title{
THE APPLICATION OF ARTIFICIAL NEURAL NETWORKS IN PREDICTING CHILDREN'S GIFTEDNESS
}

\author{
Nina Pavlin-Bernardić \\ University of Zagreb, Faculty of Humanities and Social Sciences and Croatian Studies \\ Ivana Lučića 3/Borongajska cesta 83d, 10000 Zagreb \\ nbernardi@ffzg.hr \\ Silvija Ravić \\ Elementary school Sesvetska Sela \\ Letnička 5, 10360 Sesvete \\ silvija.ravic@gmail.com \\ Ivan Pavao Matić \\ Elementary school Sesvetska Sela \\ Letnička 5, 10360 Sesvete \\ ivanpavao@gmail.com
}

\begin{abstract}
Artificial neural networks have a wide use in the prediction and classification of different variables, but their application in the area of educational psychology is still relatively rare. The aim of this study was to examine the accuracy of artificial neural networks in predicting students' general giftedness. The participants were 221 fourth grade students from one Croatian elementary school. The input variables for artificial neural networks were teachers' and peers' nominations, school grades, earlier school readiness assessment and parents' education. The output variable was the result on the Standard Progressive Matrices (Raven, 1994), according to which students were classified as gifted or non-gifted. We tested two artificial neural networks' algorithms: multilayer perceptron and radial basis function. Within each algorithm, a number of different types of activation functions were tested. $80 \%$ of the sample was used for training the network and the remaining $20 \%$ to test the network. For a criterion according to which students were classified as gifted if their result on the Standard Progressive Matrices was in the $95^{\text {th }}$ centile or above, the best model was obtained by the hyperbolic tangent multilayer perceptron, which had a high accuracy of $100 \%$ of correctly classified non-gifted students and $75 \%$ correctly classified gifted students in the test sample. When the criterion was the $90^{\text {th }}$ centile or above, the best model was also obtained by the hyperbolic tangent multilayer perceptron, but the accuracy was lower: $94.7 \%$ in the classification of non-gifted students and $66.7 \%$ in the classification of gifted students. The study has shown artificial neural networks' potential in this area, which should be further explored.
\end{abstract}

Key words: gifted students, identification of gifted students, artificial neural networks 


\section{INTRODUCTION}

Identification of gifted students should follow several recommendations, such as including all sources which can provide useful information and using several methods (e.g. Koren, Kolesarić \& Ivanec, 1998; Vojnović, 2008). However, in Croatia many schools do not conduct systematic identification of gifted children and many of them do not have a school psychologist (Vojnović, 2008). Also, sometimes in the process of identification only teachers' nominations and assessments are used, although some authors doubt that teachers are effective in identification (Gagné, 1994).

This paper explores how artificial neural networks can be used as a tool in the identification of gifted children when not all of the recommended data are available (i.e. results of ability testing).

An artificial neural network is a computational structure consisting of interconnected computational elements. In general, neural networks consist of an input layer (which represents independent variables in the model), one or more hidden layers, and an output layer, which is comparable to a categorical dependent variable (Garson, 1998). During the learning phase, artificial neural network creates a predicted outcome for each case. If this prediction is incorrect, the network makes adjustments in the hidden layer to the weights of the relationships between the predictors and the expected outcome (Musso, Kyndt, Cascallar \& Dochy, 2013). In the testing phase, the obtained weights in the model are fixed and it is observed how they predict outcomes of the remaining cases in the dataset for which the outcomes are known to the experimenter. The network can also be applied to predict new cases where the outcome is still unknown.

Artificial neural networks allow using large numbers of variables simultaneously and making use of their relationships without the usual parametric constrains. Also, they often outperform classical statistical methods due to their abilities to analyze incomplete, noisy data (Pavleković, Zekić-Sušac i Đurđević, 2011).

Artificial neural networks are a relatively new methodological approach in the areas of learning and education. In several studies they have been used to predict students' academic performance, which allows early detection of future low performance and enables effective interventions (e.g. Musso et. al., 2013; Musso \& Cascallar, 2009).

Just a few studies used artificial neural networks to predict giftedness. For example, Pavleković, Zekić-Sušac \& Đurđević (2011) tried to model a neural network capable of detecting mathematically gifted elementary school students. As input variables they used teachers' assessments of five components of mathematical giftedness, while the output variable was psychologists' assessment whether the child was mathematically gifted or not. The function with the highest accuracy correctly categorized a very high percent age of children from the test sample. 
However, programs for gifted students in schools are often intended for all students with above average intelligence and not just mathematically gifted students. Thus, the aim of this study was to examine the accuracy of neural networks in predicting elementary school students' general giftedness, using teachers' and students' assessments, as well as other available data, such as grades, school readiness and parents' education.

\section{METHODOLOGY}

We used data for 221 elementary school students (45.8\% female) from three generations who were tested in the fourth grade. Their mean age was 10.1 years. All students were from one elementary school in Zagreb which assesses students' giftedness each year.

We used these categories of variables as input variables for artificial neural networks:

Teachers'nominations. Teachers were provided with written descriptions of gifted children's characteristics for areas of giftedness from Koren's (1989) PROFNAD scale. This scale consists of six subscales: general intellectual abilities, creative abilities, specific school abilities, management, artistic and psychomotor abilities. Because the original scale consists of 48 items and is time consuming for teachers to fill them out for each child, for every area of giftedness we asked teachers to nominate up to three students from the class to whom the given description could be applied. Thus, for each child, the result for each area of giftedness could be 0 or 1 .

Peers'nominations. We used PRONAD-U scale (Koren, 1989), which also consists of six aforementioned categories of giftedness. There are three items for each of the categories and the child has to nominate three children in the class for each of them. The sample item is: "Who of your friends in class is the most successful and quickest in solving various difficult tasks?" Because the classes were of unequal sizes, for each child the result for each area of giftedness was calculated as a sum of all nominations divided by the number of children in the class, and it could vary from 0 to 3 .

School readiness. We used school's professional team's assessment of school readiness obtained before the first grade. The maximum number of points a child could get was 72. Although this assessment was not a standardized test for school readiness, we used it because sometimes such professional teams' assessments are used in schools in Croatia and despite the psychometric shortcomings it could provide useful information for artificial neural networks.

Grades. We collected children's Croatian language, mathematics, natural science and foreign language grades in the fourth grade, at the end of the semester and the end of the school year. 
Parents' education. The categories were: unfinished elementary school, completed elementary school, completed secondary school, completed college, completed university and master's degree or $\mathrm{PhD}$.

There were a total of 23 input variables. As output variable we used the students' results on Standard Progressive Matrices (SPM; Raven, 1994). For classifying students as gifted or not gifted we used a criterion according to which students were classified as gifted if their result was in the $95^{\text {th }}$ centile or above according to the norms provided in the manual (Raven, Raven \& Court, 1999); and a "less strict" criterion, according to which students were classified as gifted if their result was in the $90^{\text {th }}$ centile or above. Although the school from which the data was used uses the first criterion, we wanted to see also how neural networks would perform when the broader criterion is used.

\section{RESULTS}

Spearman's rank correlation coefficients between the variables used in the study, except teachers' nominations, and students' results on the SPM are presented in Table 1.

Table 1. Spearman's rank correlation coefficients between the variables used in the study and students' results on Standard progressive matrices

\begin{tabular}{ll}
\hline Variables & SPM \\
\hline Children's nominations: General intellectual abilities & $.37^{* *}$ \\
Children's nominations: Creative abilities & $.23^{* *}$ \\
Children's nominations: School abilities & $.42^{* *}$ \\
Children's nominations: Management abilities & $.29^{* *}$ \\
Children's nominations: Artistic abilities & $.31^{* *}$ \\
Children's nominations: Psychomotor abilities & $.14^{*}$ \\
Mother's education & $.18^{* *}$ \\
Father's education & $.17^{* *}$ \\
Croatian language grade (1 $1^{\text {st }}$ semester) & $.44^{* *}$ \\
Mathematics grade (1 $1^{\text {st }}$ semester) & $.53^{* *}$ \\
Natural sciences grade (1 $1^{\text {st }}$ semester) & $.42^{* *}$ \\
Foreign language grade (1 $1^{\text {st }}$ semester) & $.47^{* *}$ \\
Croatian language grade (end of school year) & $.45^{* *}$ \\
Mathematics grade (end of school year) & $.52^{* *}$ \\
Natural sciences grade (end of school year) & $.42^{* *}$ \\
Foreign language grade (end of school year) & $.52^{* *}$ \\
School readiness assessment & $.47^{* *}$ \\
\hline
\end{tabular}

${ }^{* *} p<.01 ; * p<.05$ 
Teachers' nominations were dichotomous variables, and for them we calculated contingency coefficients with classification of children as gifted and non-gifted according to the criterion of the $95^{\text {th }}$ centile or above on SPM and according to the criterion of the $90^{\text {th }}$ centile and above. For the first criterion, statistically significant contingency coefficients were $C=.22(p<.001)$ for general intellectual abilities, $C=$ $.17(p<.01)$ for creative abilities and $C=.14(p<.05)$ for specific school abilities. For the second criterion, statistically significant contingency coefficients were $\mathrm{C}=.20$ $(p<.001)$ for general intellectual abilities and $C=.14(p<.05)$ for creative abilities.

For testing artificial neural networks we used the application STATISTICA 8.0, which tested two algorithms: multilayer perceptron and radial basis function. Within each algorithm, a number of different types of activation functions were tested: logistic, identity, hyperbolic tangent, exponential and sine function. For each of these, the number of units in the hidden layer and number of networks to train were varied.

In order to train and test neural networks, the total sample was randomly divided into two subsamples: $80 \%$ of the data was used for training the network and the remaining $20 \%$ was used to test it. The best model was selected on the basis of the highest average hit rate obtained on the test sample.

When the criterion for categorizing children as gifted or non-gifted was a result in the $95^{\text {th }}$ centile or above on the SPM, 26 of the students were in that category. The best model was obtained by the hyperbolic tangent multilayer perceptron, which had a structure of 23-8-2 (23 neurons were in the input layer, 8 in the hidden layer and 2 in the output layer). The results for training and test phase are presented in Table 2. The model produced a hit rate of $100 \%$ for non-gifted children and $75 \%$ for gifted children in the test sample.

All of the predictions of the neural network were accompanied by confidence levels, which represent estimated probabilities that the prediction was accurate. Figure 1 shows a lift chart diagram for the best function. Lift chart graphically represents the improvement that a neural network provides when compared to a

Table 2. Results of the best artificial neural network for predicting students' giftedness (with the criterion of $95^{\text {th }}$ percentile on SPM)

\begin{tabular}{lccccc}
\hline & \multicolumn{2}{c}{ Training sample } & & \multicolumn{2}{c}{ Test sample } \\
\cline { 2 - 3 } \cline { 5 - 6 } & Non-gifted & Gifted & & Non-gifted & Gifted \\
\hline Correctly classified & 150 & 18 & & 43 & 3 \\
& $(98.7 \%)$ & $(81.8 \%)$ & & $(100 \%)$ & $(75 \%)$ \\
Incorrectly classified & 2 & 4 & & 0 & 1 \\
& $(1.3 \%)$ & $(18.2 \%)$ & & $(0 \%)$ & $(25 \%)$ \\
Total & 152 & 22 & & 43 & 4 \\
& $(100 \%)$ & $(100 \%)$ & & $(100 \%)$ & $(100 \%)$ \\
\hline
\end{tabular}




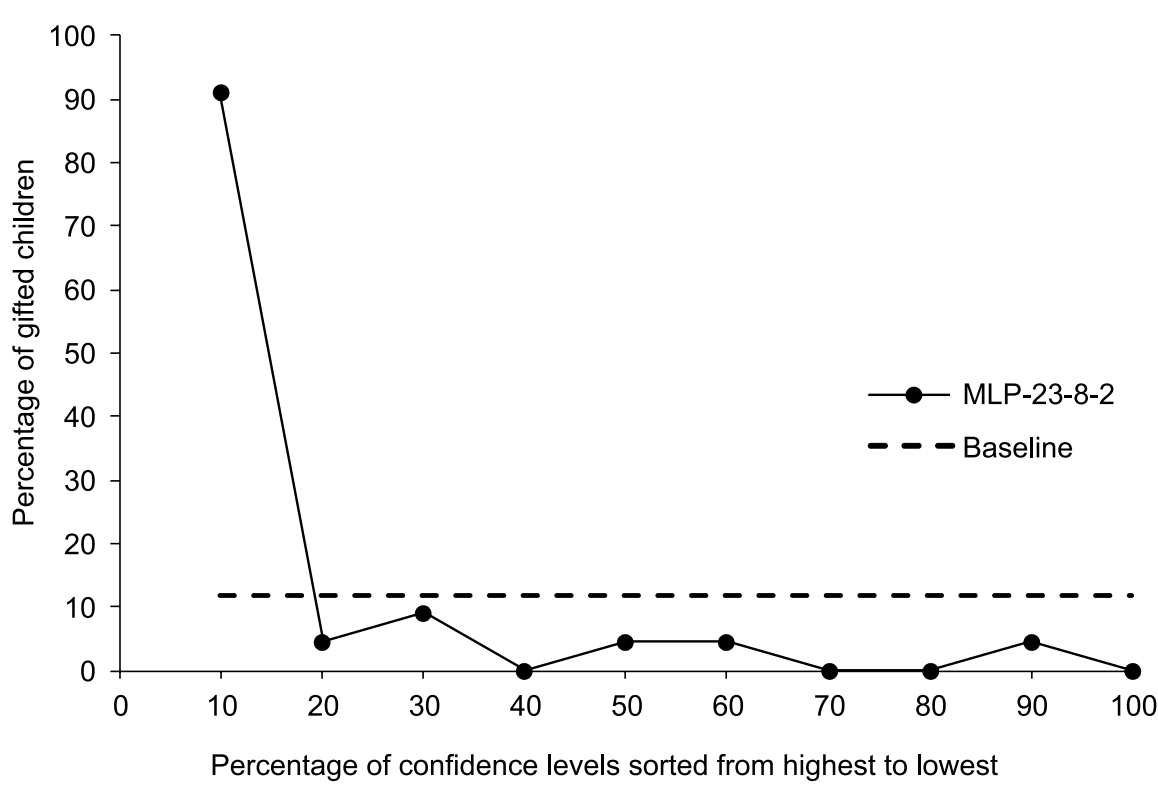

Figure 1. Lift chart diagram for the best function, with the criterion of $95^{\text {th }}$ percentile on SPM

random guess. The baseline shows what would be the percentage of accurately identified gifted students in the whole sample if confidence levels were assigned randomly (since there were $11.8 \%$ gifted children). We can see that more than $90 \%$ of students within the interval with the highest ten percent of confidence levels were correctly categorized as gifted. For the next ten percent of confidence levels in descending order the percentage of gifted students is beneath the baseline, because predictions for almost all of the gifted students had confidence levels in the highest ten percent.

When the criterion for categorizing children as gifted or non-gifted was a result of the $90^{\text {th }}$ centile or above on the SPM, 40 of the students were in that category. The best model was obtained by the hyperbolic tangent multilayer perceptron, which had a structure of 23-18-2. The results for training and test phase are presented in Table 3. In the test sample, the model produced a hit rate of $94.7 \%$ for non-gifted children and $66.7 \%$ for gifted children.

Figure 2 shows a lift chart diagram for the best function. More than $90 \%$ of students within the interval with the highest ten percent of confidence levels and more than $70 \%$ of students within the next interval were correctly categorized as gifted. Predictions for most of the participants had confidence levels in the highest twenty percent. Thus, the function for the criterion of $95^{\text {th }}$ centile was more accurate. 
Table 3. Results of the best artificial neural network for predicting students' giftedness (with the criterion of $90^{\text {th }}$ percentile on SPM)

\begin{tabular}{lccccc}
\hline & \multicolumn{2}{c}{ Training sample } & & \multicolumn{2}{c}{ Test sample } \\
\cline { 2 - 3 } \cline { 5 - 6 } & Non-gifted & Gifted & & Non-gifted & Gifted \\
\hline Correctly classified & 141 & 28 & & 36 & 6 \\
& $(98.6 \%)$ & $(90.3 \%)$ & & $(94.7 \%)$ & $(66.7 \%)$ \\
Incorrectly classified & 2 & 3 & & 2 & 3 \\
& $(1.4 \%)$ & $(9.7 \%)$ & & $(5.3 \%)$ & $(33.3 \%)$ \\
Total & 143 & 31 & & 38 & 9 \\
& $(100 \%)$ & $(100 \%)$ & & $(100 \%)$ & $(100 \%)$ \\
\hline
\end{tabular}

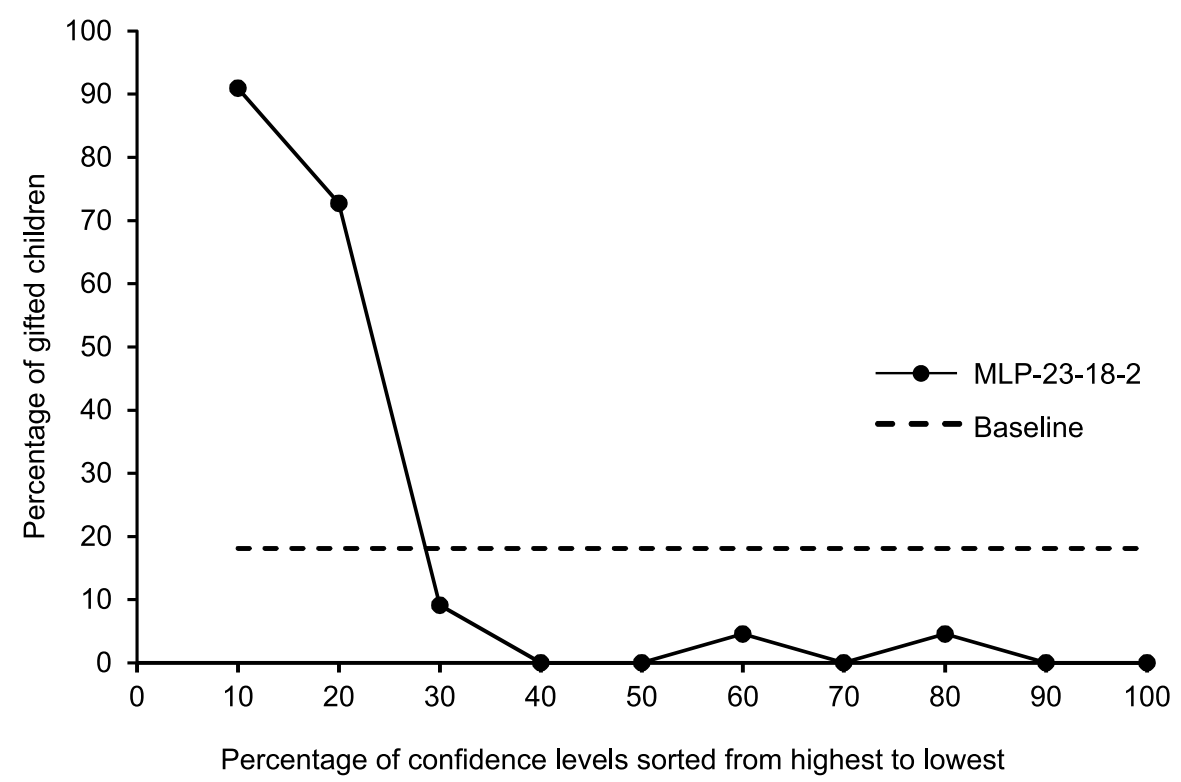

Figure 2. Lift chart diagram for the best function, with the criterion of $90^{\text {th }}$ percentile on SPM

For both neural networks we performed sensitivity analyses, which show the importance of input variables for the prediction of the output variable. Table 4 shows five variables with the highest sensitivity ratios. For both criteria these are the same variables, although their order is not quite the same.

We also performed discriminative analysis to compare its classification accuracy with neural networks' accuracy. For the criterion of the $95^{\text {th }}$ centile or above on the SPM, the hit rate of discriminative analysis was $96.4 \%$ for non-gifted and $42.3 \%$ 
Table 4. Variables with the highest sensitivity ratios

\begin{tabular}{lcc}
\hline & \multicolumn{2}{c}{ Sensitivity ratio } \\
\cline { 2 - 3 } Variables & $95^{\text {th }}$ centile & $90^{\text {th }}$ centile \\
\hline Foreign language grade (end of school year) & 1.55 & 1.52 \\
Children's nominations: School abilities & 1.34 & 1.19 \\
Children's nominations: General intellectual abilities & 1.30 & 1.38 \\
Mathematics grade (1st & 1.28 & 1.16 \\
Mother's education & 1.28 & 1.34 \\
\hline
\end{tabular}

for gifted children. For the criterion of the $90^{\text {th }}$ centile or above, hit rate was $96.6 \%$ for non-gifted and $40 \%$ for gifted children. Thus, neural networks' classifications were more accurate.

\section{DISCUSSION}

This study explored the accuracy of artificial neural networks in the identification of gifted children when not all of the recommended data are available.

Correlations between children's nominations and results on the SPM were low to moderate. The highest were for school abilities and general intellectual abilities, which could be expected since these areas are most similar to general intelligence factor which the SPM measures. Correlations for teachers' nominations were lower, which is expected because these variables were dichotomous.

Although some of the correlations between students' and teachers' nominations and results on the SPM were low or not significant, we used all of them as input variables because artificial neural networks are very good at recognizing patterns of relationships and maximizing variables' predictive ability (Detienne, Detienne \& Joshi, 2003; Musso et. al., 2013). We can see that artificial neural networks obtained high accuracy in classifying children as gifted and non-gifted.

The best results were obtained when the criterion for categorizing children as gifted or non-gifted was a result in the $95^{\text {th }}$ centile or above on the SPM. The predictions had high confidence levels and the accuracy was very high both on the training sample and on the test sample. However, there were only four gifted students in the test sample, and just one different classification would drastically change the results. Also, one of the common problems that occurs during neural network training is overfitting: the error on the training set is driven to a very small value, however when new data is presented to the network, the error is large, so the generalization of the results is questionable (Srivastava, Hinton, Krizhevsky, Sutskever $\&$ Salakhutdinov, 2014). Thus, further tests of our networks' performance should be performed on a different validation samples before the results can be generali- 
zed and used for practical purposes (helping in the identification of gifted students when the results of ability testing are not available). It is encouraging that our neural networks' classifications were more accurate than those obtained with discriminant analysis. In our further studies we plan to expand our sample and test the functions on validation samples from other schools.

As we can see, even the best neural network in our study incorrectly classified some of the gifted students in the training and test samples as non-gifted. For practical purposes, such mistakes should be minimized, because their practical repercussions are that some of the gifted students are not included in programs for the gifted.

It should also be noted that in this study we used the simplest, psychometric criterion for the identification of potentially gifted children, although giftedness is most often defined as more than just intelligence (Sternberg, 2004). The criterion we used is more useful when the children are selected for programs for gifted children in school which are more general, than for the programs for specific talents.

In their study, which obtained high accuracy of neural networks' classifications, Pavleković, Zekić-Sušac and Đurđević (2011) concluded that "the model can be suggested as a methodological tool to assist teachers in making decision about a child's mathematical gift especially in schools which have a shortage of psychologists" (pp. 21). We have to point out that psychologists are necessary for the identification of gifted children and that our opinion is by no means that intelligence tests should be replaced by artificial neural networks. However, our study has shown their potential as tools in this area, which should be further explored and tested.

\section{REFERENCES}

Detienne, K. B., Detienne, D. H., \& Joshi, S. A. (2003). Neural networks as statistical tools for business researchers. Organizational Research Methods, 6, 236-265.

Gagné, F. (1994). Are teachers really poor talent detectors? Comments on Pegnato and Birch's 1959 study of the effectiveness and efficiency of various identification techniques. Gifted Child Quarterly, 38, 124-126.

Garson, G. D. (1998). Neural networks. An introductory guide for social scientists. London: Sage Publications Ltd.

Koren, I. (1989). Kako prepoznati i identificirati nadarenog učenika [How to recognize and identify a gifted student]. Zagreb: Školske novine.

Koren, I., Kolesarić, V. \& Ivanec, D. (1998). Analiza uzroka relativne školske neuspješnosti intelektualno natprosječnih učenika [Analysis of the causes of school underachievement among intellectually superior students]. Suvremena psihologija, 1(1-2), 7-30.

Musso, M. F., \& Cascallar, E. C. (2009). New approaches for improved quality in educational assessments: Using automated predictive systems in reading and mathematics. Journal of Problems of Education in the $21^{\text {st }}$ Century, 17, 134-151. 
Musso, M. F., Kyndt, E., Cascallar, E. S., \& Dochy, F. (2013). Predicting general academic performance and identifying the differential contribution of participating variables using artificial neural networks. Frontline Learning Research, 1, 42-31.

Pavleković, M., Zekić-Sušac, M., \& Đurđević, I. (2011). A neural network model for predicting children's mathematical gift. Croatian Journal of Education, 13(1), 10-41.

Raven, J. C. (1994). Standardne progresivne matrice - SPM [Standard progressive matrices - SPM]. Jastrebarsko: Naklada Slap.

Raven, J., Raven, J. C. \& Court, H. (1999). Priručnik - 3. dio: Standardne progresivne matrice [Manual $-3^{\text {rd }}$ part: Standard progressive matrices]. Jastrebarsko: Naklada Slap.

Srivastava, N., Hinton, G., Krizhevsky, A., Sutskever, I., \& Salakhutdinov, R. (2014). Dropout: a simple way to prevent neural networks from overfitting. The Journal of Machine Learning Research, 15(1), 1929-1958.

Sternberg, R. J. (2004). Definitions and conceptions of giftedness. Thousand Oaks: Corwin Press.

Vojnović, N. (2008). Stanje, problemi i potrebe u području skrbi o darovitim učenicima u hrvatskom školskom sustavu. [Current state, problems and needs in the area of care for gifted students in Croatian school system]. In V. Vlahović-Štetić (Eds.), Daroviti učenici: teorijski pristup i primjena u školi (2. izdanje) (pp. 81-118). Zagreb: Institut za društvena istraživanja u Zagrebu.

\title{
PRIMJENA UMJETNIH NEURONSKIH MREŽA U PREDVIĐANJU DAROVITOSTI UČENIKA
}

\begin{abstract}
Sažetak
Umjetne neuronske mreže imaju široku upotrebu u predikciji i klasifikaciji različitih varijabli, no njihova primjena u području psihologije obrazovanja je još uvijek relativno rijetka. Cilj ovog istraživanja bio je ispitati točnost umjetnih neuronskih mreža u predviđanju nadarenosti učenika. U ispitivanju je sudjelovao 221 učenik 4. razreda jedne hrvatske osnovne škole. Kao ulazne varijable za umjetne neuronske mreže korištene su nominacije učitelja i drugih učenika, ocjene, ranija procjena spremnosti učenika za školu i obrazovanje roditelja. Kao izlazna varijabla korišten je rezultat učenika na Standardnim progresivnim matricama (Raven, 1994), prema kojem su učenici svrstani u darovite ili nedarovite. Testirali smo dva algoritma umjetnih neuronskih mreža: mrežu s radijalno zasnovanom funkcijom i višeslojni perceptron. Unutar svakog algoritma, testirano je više aktivacijskih funkcija. $80 \%$ uzorka korišteno je za uvježbavanje mreža, $20 \%$ za testiranje njihove uspješnosti. Za kriterij prema kojem su u darovite učenike svrstani oni koji postižu rezultat na Standardnim progresivnim matricama u 95. centilu ili više, najuspješnijom se pokazala mreža višeslojnog perceptrona s funkcijom tangens hiperbolni, koja je na testnom uzorku postigla visoku točnost od 100\% u klasifikaciji nedarovitih učenika i 75\% u klasifikaciji darovitih učenika. Kada je kriterij bio rezultat u 90. centilu ili više, najuspješnija je bila također
\end{abstract}


mreža višeslojnog perceptrona s funkcijom tangens hiperbolni, no točnost je bila niža: 94,7\% u klasifikaciji nedarovitih učenika i 66,7\% u klasifikaciji darovitih učenika. Istraživanje je pokazalo potencijal umjetnih neuronskih mreža u ovom području, koji treba dalje istražiti.

Ključne riječi: nadareni učenici, identifikacija darovitih učenika, umjetne neuronske mreže

Prihvaćeno za tisak: 07. 09. 2016. 
